\title{
PENGARUH BENTUK PENILAIAN FORMATIF TERHADAP HASIL BELAJAR IPA SETELAH MENGONTROL PENGETAHUAN AWAL SISWA
}

\author{
Muh. Ilyas Ismail \\ Fakultas Tarbiyah dan Keguruan UIN Alauddin Makassar \\ Kampus II: Jalan Sultan Alauddin Nomor 36 Samata-Gowa \\ Email: iilyasismail@yahoo.co.id
}

\begin{abstract}
Abstrak:
Penelitian ini bertujuan untuk mengidentifikasi pengaruh jenis penilaian formatif terhadap prestasi belajar Ilmu Pengetahuan Alam. Penelitian ini menggunakan 2 x 2 metode desain eksperimental faktorial. Populasi penelitian ini adalah semua siswa kelas 5 pada SD 03 dan 05 dari Rawamangun Jakarta Timur, dengan 80 siswa sebagai sampel, pelaksanaan penilaian statistik inferensial dengan ANCOVA. Studi ini menyimpulkan (1) setelah dikontrol pengetahuan awal siswa, prestasi belajar Ilmu Pengetahuan Alam kelompok, yang diberi esai penilaian tes formatif adalah perbedaan dari pencapaian mereka dengan tes pilihan ganda, (2) setelah dikontrol siswa 'pengetahuan sebelumnya, prestasi belajar Ilmu Pengetahuan Alam dari kelompok yang diberi esai penilaian tes formatif lebih tinggi dari kelompok dalam tes pilihan ganda.
\end{abstract}

\begin{abstract}
:
This research aims at identifying the effect of formative assessment type towards the learning achievement of Natural Sciences. This study applied $2 \times 2$ factorial design experimental methods. The population of the research was all the fift grade students of elementary school number 03 and 05 of Rawamangun Eastern Jakarta, with 80 students as sample, implementing inferential statistic assessment with ANCOVA. The result of the study showed that (1) having controlled the students' prior knowledge, the learning achievement of Natural Sciences of the group, which was given essay test formative assessment was different from the achievement of those with multiple choice test, (2) having controlled the students' prior knowledge, the learning achievement of Natural Sciences of the group which was given essay test formative assessment was higher than the group in multiple choice test.
\end{abstract}

\section{KEYWORDS:}

Formative assessment type, Natural Sciences, learning achievement, prior knowledge.

TERDAPAT dua prinsip pendidikan UNESCO yang sangat relevan dengan Pancasila: (1) pendidikan harus diletakkan pada empat pilar, yaitu belajar mengetahui (learning to know), belajar melakukan (learning to do), belajar hidup dalam kebersamaan (learning to live togehter), dan belajar menjadi diri sendiri (learning to be), dan (2) belajar seumur hidup (live long learning) ${ }^{1}$

Sedangkan Sholeh menjelaskan bahwa peningkatan mutu pendidikan merupakan suatu langkah yang dilakukan secara terencana, yang mencakup dua strategi yaitu: (1) merupakan perencanaan jangka pendek untuk meningkatkan kemampuan intelektual peserta didik sebagai standar minimal untuk merai tujuan pendidikan jang- 
ka panjang yang mengacu pada pengembangan manusia Indonesia seutuhnya, dan (2) mengarahkan tujuan pendidikan berlandasan luas, bermanfaat nyata, dan bermakna dalam mempersiapkan peserta didik menghadapi tantangan masa depan. ${ }^{2}$

Suryabrata menjelaskan bahwa rendahnya hasil belajar ilmu Pengetahuan Alam (IPA) siswa SD dipengaruhi oleh dua faktor, yaitu: (1) faktor internal siswa, dan (2) faktor eksternal siswa. Yang berasal dari faktor internal siswa di antaranya: sikap, minat, bakat, emosi, kecerdasan, kemampuan dan sebagainya. Sedangkan faktor eksternal siswa berkaitan dengan faktor guru, sarana dan fasilitas belajar, kurikulum, metode, model pembelajaran yang diterapkan, bentuk evaluasi yang diterapkan, tujuan, lingkungan, dan lingkungan keluarga, sekolah, serta masyarakat. ${ }^{3}$

Dalam peraturan pemerintah nomor 19 tahun 2005 tentang standar pendidikan nasional, ada 8 (delapan) standar komponen pendidikan yang harus dipenuhi dalam rangka menjamin mutu pendidikan. Dari 8 (delapan) standar komponen pendidikan yang dimaksud, ada 4 (empat) standar komponen pendidikan merupakan standar yang terkait dengan kurikulum yaitu: standar kompetensi lulusan (tujuan), standar isi (materi), standar proses pembelajaran, standar penilaian (evaluasi) pendidikan, dan 4 (empat) standar lainnya merupakan standar pendukung, standar pendidik dan tenaga kependidikan (tendik), standar sarana dan prasarana (sarpras), standar pengelolaan, dan standar pembiayaan.

Djaali menjelaskan bahwa penilaian formatif pada dasarnya adalah tes yang bertujuan untuk mendapatkan umpan balik bagi usaha perbaikan kualitas pembelajaran dalam konteks kelas. Oleh karena itu tes formatif yang diselenggarakan dalam selang waktu yang relatif pendek akan memberikan masukan atau umpan balik yang dapat digunakan oleh guru sebagai pengelola kegiatan pembelajaran dalam meningkatkan intensitas proses belajar dalam diri setiap subyek belajar melalui peningkatan kesesuaian antara tiga unsur, yaitu struktur kognitif subyek belajar, karakteristik konsep yang dipelajari, dan strategi pembelajaran yang digunakan. ${ }^{4}$

Rose menjelaskan bahwa materi pelajaran yang dipelajari pada hari ini akan terlupakan sebanyak 70\% dalam jangka waktu 24 jam apabila Anda tidak melakukan upaya khusus untuk mengingatnya artinya pelajaran harus sering diulang. ${ }^{5}$ Sedangkan Hilgard dan Bowler menjelaskan bahwa pengetahuan yang diterima melalui panca indra akan direkam ke dalam jangka panjang, pengetahuan yang tidak diulangulang dan tidak mendapat perhatian akan terdorong keluar dan terlupakan. ${ }^{6}$ Pendapat senada dikemukakan oleh Thorndike menjelaskan bahwa makin sering melakukan pengulangan-pengulangan, maka akan memperkuat hubungan antara stimulus dengan respon. ${ }^{7}$

\section{Perumusan Masalah}

Berdasarkan dari paparan masalah yang telah dikemukakan di atas, maka secara operasional, masalah dalam penelitian ini masalah dirumuskan sebagai berikut:

1. Dengan mengontrol pengetahuan awal, apakah terdapat perbedaan hasil belajar Ilmu Pengetahuan Alam (IPA) antara kelompok siswa yang diberi penilaian for- 
matif bentuk tes esai dengan kelompok siswa yang diberi penilaian formatif bentuk tes pilihan ganda?

2. Dengan mengontrol pengetahuan awal, manakah hasil belajar Ilmu Pengetahuan Alam (IPA) yang lebih tinggi antara kelompok siswa yang diberi penilaian formatif bentuk tes esai dengan kelompok siswa yang diberi penilaian formatif bentuk tes pilihan ganda?

\section{DESKRIPSI TEORETIK}

\section{Pengertian Belajar}

Gagne mengatakan bahwa belajar merupakan proses yang memungkinkan individu merubah prilakunya dalam kurun waktu yang tidak terlalu lama dan dengan cara yang relatif sama, sehingga perubahan yang sama itu tidak harus terulang pada setiap situasi berikutnya (situasi baru). ${ }^{8}$

Sudjana mengemukakan bahwa belajar adalah suatu proses aktivitas yang kompleks seperti yang dijelaskan oleh Smith dalam Sudjana bahwa belajar berarti: (1) transformasi yang terjadi dalam pikiran manusia, dan upaya pemecahan masalah, (2) proses yang terjadi dalam diri manusia yang menyebabkan terjadinya perubahan prilaku, (3) pembinaan dan pertukaran keterkaitan antar pikiran manusia dan antar pengertian yang bermakna, (4) perubahan kemampuan yang diproleh manusia, bukan karena perubahan fisik, dan (5) proses perubahan pemahaman, pandangan, harapan, dan pola pemikiran. ${ }^{9}$

Dari definisi tersebut di atas dapat diartikan bahwa belajar adalah suatu proses perubahan diri seseorang yang ditampakkan dalam bentuk peningkatan kualitas dan kuantitas tingkah laku seperti peningkatan pengetahuan, kecakapan, daya pikir, sikap, kebiasaan. belajar dan proses belajar yang telah dikemukakan di atas, maka dapatlah ditarik suatu kesimpulan bahwa belajar adalah suatu perubahan tingkah laku, penambahan pengetahuan yang permanen. Perubahan tingkah laku tersebut terjadi karena adanya aktivitas latihan dan pengalaman yang mengakibatkan perubahan kemampuan yang berlangsung secara internal maupun eksternal.

Carin dan Sund menjelaskan bhwa sains adalah suatu sistem untuk memahami semesta dengan data yang dikumpulkan melalui observasi atau eksperimen yang dikontrol. ${ }^{10}$ Definisi tersebut mengandung tiga elemen utama yakni proses (metode), produk, dan sikap manusia. Proses atau metode menekankan pada cara investigasi masalah dan observasi. Produk lebih menunjuk pada fakta, prinsip, hukum, dan teori. Sedangkan sikap manusia lebih menekankan pada keyakinan, nilai, dan pendapat.

Kadaryanto mengemukakan bahwa Ilmu Pengetahuan Alam (IPA) dikenal juga dengan nama Sains (Science) dapat dipandang dalam pengertian sempit, adalah suatu disiplin ilmu yang terdiri atas physical sciences dan life sciences. Disiplin ilmu Physical Sciences meliputi; astronomi, kimia, geologi, mineralogi, meteorologi, dan fisika. Sedangkan Life Sciences meliputi; biologi, zoologi, dan fisiologi. Sains sebagai ilmu pengetahuan adalah kumpulan konsep, prinsip, hukum, dan teori yang dibentuk melalui proses kreatif dan sistimatis (inkuiri), kemudian dilanjutkan dengan proses ob- 
servasi (empiris) secara terus menerus. Sains dilandasi dengan sikap keingintahuan (curiosity), keteguhan hati (courage), dan ketekunan (persistence) yang dilakukan oleh individu untuk menyingkap rahasia alam semesta. ${ }^{11}$

Dalam pembelajaran Ilmu Pengetahuan Alam (IPA), para siswa akan mendapat banyak kesempatan untuk mengembangkan keterampilan dengan melakukan berbagai kegiatan di antaranya; (1) mempelajari berbagai peristiwa Ilmu Pengetahuan Alam (IPA), terutama yang ada kaitannya dengan kehidupan sehari-hari, (2) mengadakan pengamatan terhadap berbagai benda atau peristiwa alam, (3) belajar menafsirkan sesuatu kejadian berdasarkan kaidah-kaidah Ilmu Pengetahuan Alam (IPA), (4) berlatih menerapkan konsep-konsep Ilmu Pengetahuan Alam (IPA) dalam kehidupan sehari-hari, (5) melakukan berbagai macam kegiatan atau percobaan Ilmu Pengetahuan Alam (IPA), dan (6) belajar mengkomunikasikan gagasan-gagasan kepada orang lain dengan bahasa yang singkat tapi jelas. Selain kegiatan pembelajaran Ilmu Pengetahuan Alam (IPA) sebagaimana yang dikemukakan di atas, siswa juga akan diperkenalkan dengan teknologi sederhana yang ada kaitannya dengan kaidahkaidah Ilmu Pengetahuan Alam (IPA) yang telah dipelajari siswa.

Gronlund mengelompokkan hasil belajar atas: (1) pengetahuan, (2) pemahaman, (3) keterampilan berpikir, (4) terampil dalam kinerja, (5) keterampilan berkomunikasi, (6) keterampilan berhitung, (7) keterampilan belajar sampil bekerja, (8) keterampilan bersosialisasi, (9) sikap, (10) minat (11) apresiasi, dan (12) penyesuaian. ${ }^{12}$

Kingsley membagi tiga bentuk hasil belajar, yaitu; (1) keterampilan dan kebiasaan, (2) pengetahuan dan pengertian, dan (3) sikap dan cita-cita. ${ }^{13}$ Sedangkan Bloom membagi hasil belajar dalam tiga ranah atau kawasan yakni; (1) ranah kognitif, (2) ranah afektif, dan (3) ranah psikomotor. ${ }^{14}$ Kemudian oleh Anderson merevisi aspek kemampuan kognitif dengan memilah dua yakni: (1) dimensi pengetahuan, dan (2) dimensi proses kognitif. ${ }^{15}$ Lebih lanjut Anderson menjelaskan bahwa dimensi pengetahuan di dalamnya memuat objek ilmu yang disusun dari: (1) pengetahuan fakta, (2) pengetahuan konseptual, (3) pengetahuan prosedural, dan (4) pengetahuan meta kognitif. Sedangkan dimensi proses kognitif memuat enam tingkatan yang meliputi: (1) mengingat, (2) mengerti, (3) mengaplikasikan, (4) menganalisis, (5) mengevaluasi, dan (6) mencipta. ${ }^{16}$

Briggs mengemukakan bahwa hasil belajar adalah seluruh kecakapan dan hasil yang dicapai oleh siswa melalui proses pembelajaran yang dinyatakan dengan angkaangka atau nilai-nilai yang diukur dengan non tes maupun dengan tes hasil belajar. ${ }^{17}$ Sedangkan Gagne menjelaskan bahwa hasil belajar adalah kapabilitas yang dapat digolongkan atas: (1) informasi verbal; kemampuan menyatakan kembali informasi yang diperoleh dari proses belajar, (2) keterampilan intelektual; melaui proses belajar seseorang akan mampu berfungsi dengan baik dalam masyarakat, (3) keterampilan motorik; kemampuan menguasai berbagai jenis keterampilan gerak, (4) sikap; kapabilitas yang mempengaruhi pilihan tentang tindakan mana yang akan dilakukan, dan (5) strategi kognitif; kapabilitas yang mengatur cara bagaimana peserta belajar mengelola belajarnya. ${ }^{18}$ 
Peraturan Menteri No. 20 tahun 2008, menyebutkan bahwa penilaian pendidikan adalah proses pengumpulan dan pengolahan informasi untuk menentukan pencapaian hasil belajar siswa (peserta didik). Permen tersebut menyebutkan bahwa penilaian hasil belajar didasarkan pada prinsip-prinsip sahih, objektif, adil, terpadu, terbuka, menyeluruh, dan berkesinambungan, sistimatis, berdasarkan kriteria, serta akuntabel.

Tessmer menyatakan bahwa penilaian formatif adalah suatu tahapan kegiatan yang dilakukan pada saat bagian materi pelajaran telah selesai diberikan kepada siswa. Penilaian ini dilakukan untuk mengetahui sajauh mana para siswa telah memahami materi pelajaran tersebut dan juga untuk mengetahui kelemahan-kelemahan yang terjadi pada proses pembelajaran, seperti ketepatan penggunaan metode pembelajaran, media, dan sistem penilaian yang digunakan. ${ }^{19}$ Jadi pada dasarnya penilaian formatif dilakukan dalam rangka memperoleh umpan balik yang tepat sehingga pembelajaran yang sedang dilaksanakan dapat disempurnakan ke arah yang lebih baik.

Guba dan Lincoln memberikan penekanan bahwa tujuan penilaian formatif adalah untuk perbaikan dan penyempurnaan apa yang telah dilakukan. ${ }^{20}$ Pengertian yang hampir sama dikemukakan oleh Sukardi dan Maramis bahwa penilaian formatif bertujuan memberi umpan balik kepada siswa tentang hasil belajar yang dicapai, apakah sudah baik atau masih ada hal-hal yang perlu diperbaiki untuk mencapai tujuan pembelajaran yang telah ditetapkan sebelumnya. ${ }^{21}$

Pendapat yang senada dikemukakan oleh Popham dan Antes menyatan bahwa penilaian formatif adalah berguna untuk mendiagnosa kekuatan dan kelemahan siswa, mengetahui perkembangan siswa, menentukan peringkat siswa, dan menentukan keefektifan pengajaran.22 Sedangkan Hopkins dan Antes mengemukakan bahwa tujuan utama penilaian formatif dalam kelas adalah untuk mengaktuali-sasikan hasil belajar siswa dimana penilaian formatif dirancang untuk mengukur hasil belajar dan dipergunakan untuk memperbaiki proses belajar mengajar guna memenuhi kebutuhan siswa. ${ }^{23}$

Berdasarkan berbagai pengertian atau batasan tentang penilaian formatif yang telah dikemukakan di atas, maka dapat disimpulkan bahwa penilaian formatif adalah penilaian yang dimaksudkan untuk memantau kemajuan belajar siswa selama proses pembelajaran berlangsung dalam suatu program pembelajaran tertentu (misalnya pada setiap selesai satu kompetensi dasar tertentu di dalam suatu proses pembelajaran) dalam rangka mendapatkan umpan balik, baik bagi siswa maupun kepada guru.

\section{Bentuk Penilaian Formatif}

\section{Penilaian Formatif Bentuk Tes Esai}

Secara ontologi tes esai adalah salah satu bentuk tes tertulis, yang susunannya terdiri atas item-item pertanyaan yang masing-masing mengandung permasalahan dan memerlukan jawaban siswa melalui uraian-uraian kata yang merefleksikan kemampuan berpikir siswa. 
Gronlund mendefinisikan tes esai sebagai suatu bentuk tes yang terdiri atas pertanyaan atau perintah yang menghendaki jawaban yang berupa uraian-uraian yang relatif panjang, siswa tidak memiliki jawaban melainkan memberi jawaban dengan kebebasan untuk mengekspresikan gagasan dengan kata-kata sendiri. ${ }^{24}$ Ebel menjelaskan bahwa tes esai adalah tes yang menghendaki siswa untuk mengemukakan jawaban dan menyatakan secara tertulis dan penskorannya dapat dilakukan berdasarkan kualitas jawaban yang diberikan oleh siswa. ${ }^{25}$

Oosterhorf menjelaskan bahwa dalam proses pelaksanaan tes esai: (1) cenderung mengukur perilaku secara lebih langsung pada tujuan pembelajaran yang telah ditetapkan, (2) menguji kemampuan siswa dalam mengkomunikasikan idenya secara tertulis, dan (3) item tes esai mengharuskan siswa memberikan jawaban tidak hanya sekedar memili jawaban yang telah ada. ${ }^{26}$

Tes esai juga digunakan untuk mengembangkan secara penuh kemampuan siswa dalam memberikan jawaban atau tanggapan atas pertanyaan yang diberikan. Tes esai selain memerlukan kemampuan ingatan dan penerapan akan suatu konsep juga membutuhkan ketajaman analisis dan interpretasi sangat diperlukan dalam menjawab tes.

\section{Penilaian Formatif Bentuk Tes Pilihan Ganda}

Popham mengemukakan bahwa tes pilihan ganda merupakan bentuk soal yang jawabannya dapat dipilih dari beberapa kemungkinan jawaban yang telah disediakan. ${ }^{27}$ Konstruksinya terdiri atas pokok soal dan pilihan jawaban. Pilihan jawaban terdiri atas kunci jawaban dan pengecoh. Kunci jawaban harus merupakan jawaban benar atau paling benar, sedangkan pengecoh merupakan jawaban tidak benar, namun daya jebaknya harus berfungsi, artinya siswa memungkinkan memilihnya jika tidak menguasai materinya.

Arikunto mengemukakan bahwa tes pilihan ganda (objektif) adalah tes yang keseluruhan informasi yang diperlukan untuk menjawab tes telah tersedia. Butir soal telah mengandung kemungkinan jawaban yang harus dipilih atau dikerjakan oleh peserta tes. ${ }^{28}$ Nitko mengemukakan bahwa tes pilihan ganda pada dasarnya terdiri dari dua bagian, yaitu batang tubuh tes (stem), berupa pertanyaan pengantar atau pertanyaan tidak lengkap, dan dua atau lebih kemungkinan jawaban (options). Secara teknis jawaban yang benar disebut kunci jawaban (key answer) dan yang lain disebu sebagai pengecoh (distractor option). Pengecoh berfungsi untuk mengalihkan perhatian peserta tes yang kurang pasti sikapnya terhadap jawaban yang benar. Jumlah alternatif jawaban yang benar pada umumnya tiga atau empat. ${ }^{29}$

Cangelosi menjelaskan bahwa tes pilihan ganda mempunyai beberapa keunggulan sebagai berikut; (1) penilaiannya yang sangat objektif, sebuah jawaban hanya mempunyai dua kemungkinan, benar atau salah. Kunci jawaban memberikan informasi apakah jawaban anak benar atau salah. Toleransi di antara salah dan benar tidak diberikan karena tingkat kebenarannya bersifat objektif, (2) memiliki reliabilitas yang tinggi, siapapun yang menilai dan kapanpun dinilai, hasilnya akan tetap sama, dan (3) butir soal tes pilihan ganda dimungkinkan dapat ditulis dalam jumlah banyak, jika 
butir soal yang dibuat banyak, maka memungkinkan untuk mencakup semua daerah prestasi yang hendak diukur, sehingga butir soal menjadi representatif, (4) dapat dikonstruksi untuk mengukur segala level tujuan pembelajaran, kecuali kemampuan untuk mendemonstrasikan keterampilan menyatakan sesuatu yang ekspresif, (5) dapat dikonstruksi untuk membedakan berbagi tingkat kebenaran sekaligus, dengan cara peserta tes diminta untuk memilih satu jawaban yang paling benar diantara sekian alternatif jawaban yang benar, (6) jumlah pilihan yang disediakan lebih dari dua, sehingga dapat mengurangi kemungkinan benar jika peserta tes menebak, (7) memungkinkan dilakukan analisis butir tes secara baik, sehingga butir-butir tes yang berkualitas dapat digunakan beberapa kali, (8) tingkat kesukaran butir tes dapat dikendalikan hanya dengan mengubah tingkat homogenitas alternatif jawabannya, dan (8) Informasi yang diberikan lebih kaya. ${ }^{30}$

Nitko menjelaskan bahwa keterbatasan butir tes pilihan ganda adalah: (1) siswa harus memilih jawaban yang telah tersedia ketimbang mengemukakan ide atau pendapat sendiri, (2) jika tidak mampu menulis tes maka ada kecenderungan butirbutir tes ini hanya mengukur aspek-aspek ingatan yang dangkal dan terbatas, (3) penggunaan kata-kata yang mendua dan membingungkan menyebabkan siswa yang pintar tidak mampu memilih dari beberapa kemungkinan jawaban yang tersedia, (4) acapkali pembuat tes hanya memikirkan jawaban yang benar, sedangkan pengecohnya tidak pernah dipersoalkan sehingga kemungkina jawabannya tidak homogen, dan (5) kurang efektif untuk mengukur hasil belajar pada ranah kognitif tingkat tinggi. ${ }^{31}$

Jika merujuk pada kutipan di atas, maka dapat dipahami bahwa tes pilihan ganda dapat diskor dengan mudah, cepat, dan memiliki objektifitas yang tinggi, mengukur berbagai tingkatan kognitif, serta dapat mencakup ruang lingkup materi yang luas dalam suatu tes. Bentuk ini sangat tepat digunakan untuk ujian berskala besar yang hasilnya harus segera diumumkan, seperti ujian nasional, ujian akhir sekolah, dan ujian seleksi pegawai negeri. Hanya saja, untuk menyusun soal pilihan ganda yang bermutu perlu waktu lama dan biaya cukup besar disamping itu penulis soal akan kesulitan membuat pengecoh yang homogen dan berfungsi, terdapat peluang untuk menebak kunci jawaban, dan peserta mudah mencontek kunci jawaban. Secara umum, setiap soal pilihan ganda terdiri dari pokok soal (stem) dan pilihan jawaban (option). Pilihan jawaban terdiri atas kunci jawaban dan pengecoh (distractor).

\section{Pengetahuan Awal Ilmu Pengetahuan Alam (IPA)}

Reigeluth menjelaskan bahwa pengetahuan awal yang juga biasa disebut dalam istilah entry level, yaitu seluruh kompetensi pada level bawah yang seharusnya telah diketahui atau dikuasai oleh siswa sebelum siswa memulai suatu rangkaian pembelajaran khusus untuk mengerjakan kompetensi yang ada di atas kemampuan awal. ${ }^{32}$

Sedangkan Hamalik mengaitkan pengetahuan awal dengan prilaku awal (entry behavior) sebagai tingkah laku yang harus diproleh siswa sebelum memproleh tingkah laku terminal tertentu yang baru. ${ }^{33}$ Winkel menjelaskan bahwa pengetahuan awal 
adalah sebagai pengetahuan yang diperlukan sebagai (prasyarat) untuk mencapai tujuan instruksional. ${ }^{34}$ Sedangkan Tafsir menjelaskan bahwa pengetahuan awal sebagai gambaran tingkah laku yang harus dimiliki siswa sebelum ia memproleh tingkah laku yang baru sebagaimana yang terlukis dalam tujuan instruksinal khusus. ${ }^{35}$

Selanjutnya Degeng menegaskan bahwa pengetahuan awal yang ada pada diri siswa berguna sebagai pijakan dalam pemilihan strategi pengajaran yang optimal. Kemudian lebih lanjut ia menjelaskan bahwa pengetahuan awal amat penting perannya dalam meningkatkan kebermaknaan pengajaran, yang selanjutnya membawa dampak dalam memudahkan proses-proses internal yang berlangsung dalam diri siswa ketika proses belajar terjadi. ${ }^{36}$

Dari beberapa pengertian di atas dapat disimpulkan bahwa pengetahuan awal Ilmu Pengetahuan Alam (IPA) siswa adalah kemampuan kognitif yang telah diperoleh siswa sebelum menerima pelajaran baru. Pengetahuan itu merupakan kemampuan dasar yang dipersyaratkan kepada siswa untuk memudahkan mempelajari pelajaran baru atau pelajaran lanjutan.

\section{METODE PENELITIAN}

Secara umum penelitian ini bertujuan untuk mengetahui pengaruh intensitas penilaian formatif dan bentuk penilaian formatif terhadap hasil belajar IPA pada siswa Sekolah Dasar (SD), setelah mengontrol pengetahuan awal siswa.

Penelitian ini dilaksanakan di SDN 03 pagi dan SDN 05 pagi Kel. Rawamangun, Kec. Pulo Gadung Jakarta Timur. Waktu pelaksanaan Penelitian ini adalah semester ganjil pada kelas V tahun akademik 2010/2011.

Penelitian ini dilakukan dengan pendekatan kuantitatif, menggunakan metode penelitian eksperimen. Secara spesifik penelitian eksperimen ini menggunakan teknik quasi eksperimen atau eksperimen lapangan.

Penelitian ini menempatkan: (1) intensitas penilaian formatif (treatment variable) sebagai variable bebas perlakuan, (2) hasil belajar IPA dengan skala data numerik sebagai variabel terikat (criterion variable), dan (3) pengetahuan awal IPA dengan skala numerik sebagai variabel bebas kovariat. Penelitian ini menggunakan design analisis kovarian (ANKOVA) dengan faktorial.

Tabel 1. Desain Eksperimen Faktorial (2x2)

\begin{tabular}{|c|c|c|}
\hline $\begin{array}{c}\text { Bentuk Penilaian Formatif } \\
(B)\end{array}$ & \multicolumn{2}{|c|}{} \\
\hline Bentuk Tes Esai $\left(B_{1}\right)$ & $\begin{array}{c}{[X, Y]_{11 \mathrm{k}}} \\
\mathrm{k}=1,2, \ldots, \mathrm{n}_{11}\end{array}$ & $\begin{array}{c}{[X, Y]_{21 \mathrm{k}}} \\
\mathrm{k}=1,2, \ldots, \mathrm{n}_{21}\end{array}$ \\
\hline Bentuk Tes PG $\left(B_{2}\right)$ & $\begin{array}{c}{[X, Y]_{12 \mathrm{k}}} \\
\mathrm{k}=1,2, \ldots, \mathrm{n}_{12}\end{array}$ & $\begin{array}{c}{[X, Y]_{22 \mathrm{k}}} \\
\mathrm{k}=1,2, \ldots, \mathrm{n}_{22}\end{array}$ \\
\hline
\end{tabular}


Keterangan:

$\mathrm{B}_{1}$ : $\quad$ Penilaian formatif bentuk tes esai

$\mathrm{B}_{2}$ : $\quad$ Penilaian formatif bentuk tes pilihan ganda.

$X$ : $\quad$ Skor pengetahuan awal siswa dalam Ilmu Pengetahuan Alam (IPA)

Y : $\quad$ Skor hasil belajar Ilmu Pengetahuan Alam (IPA)

k : Banyaknya sampel

Prosedur perlakuan penelitian ini dilakukan melalui tiga tahap, yaitu: (1) tahap persiapan, (2) tahap pelaksanaan, dan (3) tahap akhir perlakuan.

Populasi target dalam penelitian ini adalah seluruh siswa SD 03 dan SD 05 pagi Kelurahan Rawamangun Kecamatan Pulo Gadung Jakarta Timur tahun pelajaran 2010/2011. Populasi terjangkau adalah seluruh siswa kelas V SD 03 SD 05 pagi. Sampel penelitian sebanyak 80 siswa. Kerlinger mengemukakan bahwa sampel penelitian diambil dari populasi terjangkau. ${ }^{37}$ Pengambilan sampel penelitian baik pada kelas eksperimen maupun pada kelas kontrol dilakukan dengan teknik random sederhana.

Teknik analisis data yang digunakan ada dua yaitu: (a) analisis deskriptif,dan (b) analisis inferensial, tetapi terlebih dahulu dilakukan uji prasyarat analisis yaitu uji normalitas, uji homogenitas, uji kelinieran, uji keberartian regresi kovariat terhadap variabel terikat, dan uji kesejajaran regresi.

Hipotesis yang diuji dalam penelitian ini yaitu tentang Pengaruh Bentuk Penilaian Formatif $(B)$ terhadap Hasil Belajar Ilmu pengetahuan Alam $(Y)$ dengan Mengontrol Pengetahuan Awal Ilmu Pengetahuan Alam $(X)$ siswa

Model regresi homogen yang diuji yaitu: $Y_{i j k}=\mu+B_{i}+X+\varepsilon_{i j}$ Dimana:

$Y_{i j k}=$ menyatakan nilai observasi responden ke-k dalam sel $(i, j)$

$\mu=$ menyatakan parameter konstanta secara keseluruhan

$B_{\text {in }}=$ menyatakan parameter pengaruh tingkat atau perlakuan ke-i dari faktor bentuk penilaian formatif $(B)$

$X=$ skor sebuah variabel bebas atau kovariat tunggal

$\varepsilon_{i j}=$ menyatakan suatu kesalahan random

\section{HASIL PENELITIAN}

\section{Hasil Analisis deskriptif}

Berikut ini disajikan hasil analisis deskriptif data mengenai skor hasil belajar IPA kelompok eksperimen, pengetahuan awal IPA kelompok eksperimen, hasil belajar IPA kelompok control, dan pengetahuan awal IPA kelompok kontrol.

Data lengkap rangkuman skor hasil belajar IPA dan pengetahuan awal IPA untuk kedua kelompok dapat dilihat pada tabei berikut: 
Tabel 2. Rekapitulasi Skor Pengetahuan Awal dan Hasil Belajar IPASiswa pada Semua Kelompok Penelitian

\begin{tabular}{|c|c|c|c|c|c|c|c|}
\hline \multicolumn{2}{|c|}{$\begin{array}{l}\text { Bentuk } \\
\text { Penilaian } \\
\text { Formatif }\end{array}$} & $X_{i}$ & $Y_{i}$ & $X_{i}$ & $Y_{i}$ & $X_{i}$ & $Y_{i}$ \\
\hline \multirow{5}{*}{$B_{1}$} & $n$ & 20 & 20 & 20 & 20 & 40 & 40 \\
\hline & $\bar{X} / \bar{Y}$ & 73,70 & 82,50 & 59,30 & 68,50 & 65,30 & 78,75 \\
\hline & $S$ & 18,27 & 8,39 & 11,55 & 5,34 & 14,03 & 8,72 \\
\hline & Min & 30 & 63 & 43 & 72 & 30 & 60 \\
\hline & $\operatorname{Max}$ & 90 & 90 & 85 & 90 & 85 & 92 \\
\hline \multirow{5}{*}{$B_{2}$} & $n$ & 20 & 20 & 20 & 20 & 40 & 40 \\
\hline & $\overline{\bar{X}} / \bar{Y}$ & 61,05 & 76,10 & 68,35 & 81,50 & 64,30 & 75,08 \\
\hline & $S$ & 10,35 & 5,25 & 16,16 & 6,19 & 13,50 & 6,87 \\
\hline & Min & 46 & 76 & 27 & 54 & 30 & 67 \\
\hline & $\operatorname{Max}$ & 88 & 93 & 82 & 76 & 87 & 97 \\
\hline
\end{tabular}

\section{Hasil Pengujian Prasyaratan Analisis}

\section{Uji Normalitas}

Uji normalitas dilakukan untuk mengetahui apakah data dari masing-masing kelompok berasal dari populasi berdistribusi normal atau tidak. Dalam penelitian ini, uji normalitas data dianalisis dan diuji dengan teknik uji Lilliefors, untuk hipotesis statistik:

$\mathrm{H}_{0}$ : Data berasal dari populasi berdistribusi normal

$\mathrm{H}_{1}$ : Data tidak berasal dari populasi berdistribusi normal

Kriteria pengujian yaitu: terima $\mathrm{H}_{0}$ jika $\mathrm{L}_{\mathrm{o}}<\mathrm{L}_{\text {tabel, }}$ dan tolak $\mathrm{H}_{0}$ jika $\mathrm{L}_{\mathrm{o}}>\mathrm{L}_{\text {tabel. }}$. Pengujian normalitas digunakan taraf sigifikansi $a=0,05$, dengan $n=20$, nilai $L_{t}=$ 0,190, dan $\mathrm{n}=40$, nilai $\mathrm{L}_{\mathrm{t}}=0,140$. Rangkuman hasil perhitungan ditunjukkan dalam tabel di bawah ini.

Tabel 3. Rangkuman Hasil perhitungan uji Normalitas Data Hasil Belajar IPA

\begin{tabular}{|c|c|c|c|c|}
\hline \multicolumn{5}{|c|}{$\operatorname{Siswa}\left(Y_{i j}\right)$} \\
\hline Kelpk & $\mathrm{n}$ & Lo & Lt & Kesimpulan \\
\hline$B_{1}$ & 40 & 0,132 & 0,140 & Berdistribusi normal \\
\hline$B_{2}$ & 40 & 0,130 & 0,140 & Berdistribusi normal \\
\hline
\end{tabular}

Semua kelompok hasil belajar IPA $\left(Y_{i j}\right)$ yang diuji normalitasnya dengan uji Lilliefors memberikan nilai $\mathrm{L}_{\mathrm{o}}$ atau nilai Lilliefors untuk hasil observasi lebih kecil dibandingkan dengan nilai $L_{\text {tabel, }}$ pada taraf sigifikansi $\alpha=0,05$ dengan $n=20$, nilai $L_{t}=$ 0,190, dan $n=40$, nilai $L_{t}=0,140$. Sehingga disimpulkan bahwa seluruh kelompok data hasil belajar IPA dalam penelitian ini berasal dari populasi yang berdistribusi normal. Dengan demikian, persyaratan kenormalan data dapat dipenuhi. 


\section{Uji Homogenitas}

\section{Uji-F}

Uji-F digunakan untuk menguji homogenitas data yang terdiri atas dua kelompok yaitu dalam penelitian ini digunakan untuk menguji homogenitas antara kelompok data $A_{1}$ dan $A_{2}$ serta menguji homogenitas data antara kelompok $B_{1}$ dan $B_{2}$. Kadir (2010:118), Proses analisis dan pengujian homogenitas dapat dihitung dengan menggunakan rumus:

$$
F=\frac{\text { VariansTer } \quad \text { besar }(b)}{\text { VariansTer } \quad \text { kecil }(k)}=\frac{\boldsymbol{S}_{b}^{2}}{\boldsymbol{S}_{k}^{2}}
$$

Untuk menguji hipotesis:

$\mathrm{H}_{0}: \sigma_{1}^{2}=\sigma_{2}^{2} \quad$ (varian kedua kelompok homogen)

$\mathrm{H}_{1}: \sigma_{1}^{2} \neq \sigma_{2}^{2} \quad$ (varian kedua kelompok tidak homogen)

Pengujian dilakukan pada taraf signifikansi $\alpha=0,05$ dengan cara membandingkan nilai $F_{\text {hitung }}$ dengan nilai $F_{\text {tabel }}$ Kriteria pengujian yaitu: terima $\mathrm{H}_{0}$ jika $F_{\text {hitung }}<F_{\text {tabel, }}$ dan tolak $\mathrm{H}_{0}$ jika $F_{\text {hitung }}>F_{\text {tabel }}$.

Hasil analisis dengan bantuan program Microsoft Excel 2007 diperoleh hasil:

\section{2). Uji Homogenitas Data antara Kelompok $B_{1}$ dan $B_{2}$}

Dari perhitungan seperti dalam lampiran diperoleh nilai $F_{\text {hitung }}=1,677$ dibulatkan menjadi 1,68. dengan nilai $F_{\text {tabel }}=1,71$. dengan menggunakan taraf signifikansi $\alpha=$ 0,05 dan $\mathrm{dk}_{1}=39$ serta $\mathrm{dk}_{2}=39$. Dengan demikian $F_{\text {hitung }}<F_{\text {tabel, }}$ sehingga $\mathrm{H}_{0}$ diterima dan disimpulkan antara kelompok $B_{1}$ dan $B_{2}$ memiliki varians yang homogen.

\section{Uji Linearitas}

Pengujian kelinearan regresi ini dilakukan untuk menguji, apakah model persamaan regresi kovariat $\boldsymbol{X}$ atas variabel terikat $\boldsymbol{Y}$ berbentuk linear atau tidak. Hal ini, karena pengujian statistik inferensial dengan ANKOVA mensyaratkan bahwa model persamaan regresi kovariat $X$ atas variabel terikat $Y$ harus linear. Pengujian kelinearan dilakukan dengan uji Deviasi dari Kelinearan dengan hipotesis statistik berikut.

$\mathrm{H}_{0}: \hat{Y}=a+b X$ (model regresi linear)

$\mathrm{H}_{1}: \hat{Y} \neq a+b X$ (model regresi tidak linear).

Pengujian kelinearan ini menggunakan taraf sigifikansi $\alpha=0,05$, dengan kriteria pengujian, yaitu: terima $\mathrm{H}_{0}$ jika $F_{\text {hitung }}<\mathrm{F}_{\text {tabel }}$ pada taraf $\mathrm{a}=0,05$, dan tolak $\mathrm{H}_{0}$ jika $F_{\text {hitung }}>F_{\text {tabel }}$ pada taraf $\alpha=0,05$.

Tabel 4. ANOVA untuk Uji Linearitas

\begin{tabular}{|c|c|c|c|c|c|c|c|}
\hline \multicolumn{2}{|c|}{ Sumber Varian } & JK & $\mathrm{db}$ & RJK & Fhitung & $\begin{array}{c}F_{\text {tabel }} \\
a=0,05\end{array}$ & $\begin{array}{c}F_{\text {tabel }} \\
a=0,01\end{array}$ \\
\hline \multirow[t]{3}{*}{$\begin{array}{l}\text { Antara } \\
\text { Group }\end{array}$} & (Comb) & 3516,125 & 29 & 121,246 & 3,228 & & \\
\hline & Keline & 1947,698 & 1 & 1947,698 & 51,854 & & \\
\hline & DK & 1568,427 & 28 & 56,015 & 1,491 & 1,69 & 2,10 \\
\hline \multicolumn{2}{|c|}{ Dalam Group } & 1878,075 & 50 & 37,562 & & & \\
\hline \multicolumn{2}{|l|}{ Total } & 5394,200 & 79 & & & & \\
\hline
\end{tabular}


Dari tabel 4. diperoleh nilai sig. dalam baris Deviasi dari Kelinearan adalah sebesar $F_{\text {hitung }}=1,49<\mathrm{F}_{\text {tabel }}=1,69$ pada taraf $a=0,05$, demikian halnya pada taraf $\alpha=$ 0,01, juga diperoleh $F_{\text {hitung }}=1,49<\mathrm{F}_{\text {tabel }}=2,10$ sehingga dapat disimpulkan bahwa $\mathrm{H}_{0}$ diterima, yaitu model regresi pengaruh pengetahuan awal Ilmu Pengetahuan Alam (IPA) terhadap hasil belajar Ilmu Pengetahuan Alam (IPA) berpola linear.

\section{Uji Keberartian Pengaruh Regresi}

Pengujian keberartian pengaruh regresi dimaksudkan untuk mengetahui apakah pengetahuan awal IPA sebagai variable kovariat $X$ memiliki pengaruh yang signifikan atau tidak terhadap hasil belajar IPA sebagai variabel terikat $Y$. Pegujian ini dilakukan dengan uji keberartain koefisien regresi $\hat{Y}=a+b X$ menggunakan uji-F. Pengujian keberartian regresi ini dengan hipotesis statistik sebagai berikut:

$\mathrm{H}_{0}: \beta=0$

$\mathrm{H}_{1}: \beta \neq 0$.

Pengujian keberartian pengaruh pengetahuan awal IPA sebagai variabel kovariat $\boldsymbol{X}$ terhadap hasil belajar IPA sebagai variabel variabel terikat $\mathbf{Y}$ menggunakan taraf sigifikansi $a=0,05$. Kriteria pengujian, yaitu: terima $\mathrm{H}_{0}$ jika $F_{\text {hitung }}>F_{\text {tabel }}$ pada taraf $\alpha=0,05$, dan tolak $\mathrm{H}_{0}$ jika $F_{\text {hitung }}<F_{\text {tabel }}$ pada taraf $\alpha=0,05$.

Tabel 5. ANOVA untuk Uji Keberartian Regresi

\begin{tabular}{|c|c|c|r|l|c|c|}
\hline Model & $\mathrm{JK}$ & $\mathrm{db}$ & \multicolumn{1}{c|}{ RJK } & $F_{\text {hitung }}$ & $\begin{array}{c}F_{\text {tabel }} \\
a=0,05\end{array}$ & $\begin{array}{c}F_{\text {tabel }} \\
a=0,01\end{array}$ \\
\hline Regresi & 1947,698 & 1 & 1947,698 & 44,080 & 3,96 & 6,96 \\
Residu & 3446,502 & 78 & 44,186 & & & \\
Total & 5394,200 & 79 & & & & \\
\hline
\end{tabular}

Dari tabel 4.20. diperoleh nilai sig pada baris Regresi adalah diperoleh nilai $F_{\text {hitung }}=44,080>F_{\text {tabel }}=6,96$ pada taraf $\alpha=0,01$, sehingga $\mathrm{H}_{0}$ ditolak dan disimpulkan bahwa variabel kovariat $X$ pengetahuan awal IPA memberikan pengaruh yang signifikan terhadap hasil belajar IPA $(Y)$, maka pada taraf $\alpha=0,05$, diperoleh pengaruh variabel kovariat $X$ pengetahuan awal IPA yang lebih signifikan terhadap hasil belajar IPA ( $Y$ ), dengan nilai $F_{\text {hitung }}=44,080>F_{\text {tabel }}=3,39$.

\section{Uji Kesejajaran Garis Regresi}

Pengujian kesejajaran garis regresi dimaksudkan unuk mengetahui perbedaan pengaruh linier pengetahuan awal IPA $(X)$ terhadap hasil belajar IPA $(Y)$, antar keempat kelompok sel yang dibentuk oleh faktor intensitas penilaian formatif $(A)$, dan faktor bentuk penilaian formatif $(B)$.

Hipotesis statistik sebagai berikut:

$\mathrm{H}_{0}:\left[F S^{*} X\right]_{s}=0$, untuk semua s (regresi dari semua sel sejajar)

$\mathrm{H}_{1}$ : Bukan $\mathrm{H}_{0}$ (ada regresi yang tidak sejajar).

Proses pengujian hipotesis di atas dilakukan dengan uji-F untuk sumber varian $F S^{*} X$ enggunakan taraf signifikansi $\alpha=0,05$ dengan kriteria pengujian: terima $\mathrm{H}_{0}$ jika nilai $F_{\text {hitung }}<F_{\text {tabel }}$, dan tolak $\mathrm{H}_{0}$ jika nilai $F_{\text {hitung }}>F_{\text {tabel }}$. 
Tabel 6. Hasil Analisis untuk Uji Kesejajaran Garis Regresi Berdasarkan Data $(F S, X, Y)$

\begin{tabular}{|c|c|c|c|c|c|c|}
\hline \multirow{2}{*}{ Sumber Varians } & \multirow{2}{*}{$\mathrm{JK}_{\text {res }}$} & \multirow{2}{*}{$\mathrm{Db}$} & \multirow{2}{*}{ RJK } & \multirow{2}{*}{$F_{\text {hitung }}$} & \multicolumn{2}{|c|}{$F_{\text {tabel }}$} \\
\hline & & & & & $a=0,05$ & $a=0,05$ \\
\hline Model Dikoreksi & $3406,498(a)$ & 7 & 486,643 & 17,628 & & \\
\hline Intercept & 8652,249 & 1 & 8652,249 & 313,408 & & \\
\hline$X$ & 812,399 & 1 & 812,399 & 29,427 & & \\
\hline FS & 68,537 & 3 & 22,846 & 0,828 & & \\
\hline $\mathrm{FS} * \mathrm{X}$ & 74,454 & 3 & 24,818 & 0,899 & 2,72 & 4,04 \\
\hline Kesalahan & 1987,702 & 72 & 27,607 & & & \\
\hline Total & 484036,000 & 80 & & & & \\
\hline Total Dikoreksi & 5394,200 & 79 & & & & \\
\hline
\end{tabular}

Berdasar pada tabel 6. pada baris $F S^{*} X$ di atas diperoleh nilai $F_{\text {hitung }}=0,899<$ $F_{\text {tabel }}=2,72$ pada taraf $\alpha=0,05$ sehingga $\mathrm{H}_{0}$ diterima, jika dibandingkan dengan $\alpha=$ 0,01, maka $F_{\text {hitung }}=0,899<F_{\text {tabel }}=4,04$ sehingga Ho lebih signifikan diterima dan disimpulkan bahwa tidak ada perbedaan kemiringan garis regresi (slopes) yang signifikan dari semua faktor sel atau kelompok sampel penelitian.

\section{Pengujian Hipotesis Penelitian}

\section{Pengujian Hipotesis Utama}

Model analisis yang digunakan adalah analisis kovarian (ANKOVA), dengan menggunakan prosedur GLM Univariate dengan tujuan untuk menguji pengaruh faktor utama (main effect) terhadap hasil belajar IPA dengan mengontrol pengetahuan awal IPA siswa.

Hipotesis statistik sebagai berikut:

Ho : $\mu \mathrm{A}_{1} \leq \mu \mathrm{A}_{2}$

$\mathrm{H}_{1}: \mu \mathrm{A}_{1}>\mu \mathrm{A}_{2}$

Tabel 5. Statistik Uji-F tentang $A B A^{*} B$ terhadap Hasil Belajar IPA $Y$ dengan Mengontrol $X$

\begin{tabular}{|l|r|r|r|r|l|r|}
\hline \multirow{2}{*}{ Sumber Varian } & \multicolumn{1}{|c|}{$\mathrm{JK}_{\mathrm{res}}$} & $\mathrm{db}$ & \multicolumn{1}{|c|}{$\mathrm{RJK}$} & \multicolumn{2}{|c|}{$F_{\text {hitung }}$} & \multicolumn{2}{|c|}{$F_{\text {tabel }}$} \\
\cline { 5 - 6 } & & & & & $\mathrm{a}=0,05$ & $\mathrm{a}=0,01$ \\
\hline Model Dikoreksi & $3332,043(\mathrm{a})$ & 4 & 833,011 & 30,296 & & \\
Intercept & 10854,687 & 1 & 10854,687 & 394,782 & & \\
X & 763,443 & 1 & 763,443 & 27,766 & & \\
B & 301,872 & $\mathbf{1}$ & $\mathbf{3 0 1 , 8 7 2}$ & $\mathbf{1 0 , 9 7 9}$ & \multirow{3}{*}{, 96} & $\mathbf{6 , 9 6}$ \\
Kekeliruan & 2062,157 & 75 & 27,495 & & & \\
Total & 484036,000 & 80 & & & & \\
Total Dikoreksi & 5394,200 & 79 & & & & \\
\hline
\end{tabular}


Perbedaan Hasil Belajar IPA Siswa yang Diberi Penilaian Formatif Bentuk Tes Esai dengan yang Diberi Penilaian Formatif Bentuk tes Pilihan Ganda Setelah mengontrol pengetahuan awal IPA Siswa.

Hipotesis statistik sebagai berikut:

Ho : $\mu \mathrm{B}_{1} \leq \mu \mathrm{B}_{2}$

$\mathrm{H}_{1}: \mu \mathrm{B}_{1}>\mu \mathrm{B}_{2}$

Berdasarkan Hasil analisis pengujian hipotesis 1 menunjukkan bahwa nilai statisti Uji-F di atas pada baris $\boldsymbol{B}$ terlihat bahwa pada taraf $\alpha=0.05$, maka nilai $F_{\text {hitung }}=$ 10,979, lebih besar dari $F_{\text {tabel }}=3,96$ sehingga signifikan $\mathrm{H}_{0}$ ditolak, yang berarti bahwa terdapat perbedaan terhadap hasil belajar IPA kelompok siswa yang diberi penilaian formatif bentuk tes esai dengan kelompok siswa yang diberi penilaian formatif bentuk tes pilihan ganda dengan mengontrol pengetahuan awal IPA siswa.

\section{Pengujian Hipotesis Satu Pihak}

Hipotesis yang diuji yaitu: Diduga bahwa hasil belajar IPA Siswa yang diberikan diberi penilaian formatif bentuk tes esai, dengan kelompok siswa yang diberi penilaian formatif bentuk tes pilihan ganda setelah mengontrol pengetahuan awal IPA siswa.

Hipotesis statistik sebagai berikut:

Ho : $\mu B_{1} \leq \mu B_{1}$

$\mathrm{H}_{1}: \mu \mathrm{B}_{1}>\mu \mathrm{B}_{1}$

Tabel 6. Statistik Uji-t tentang hasil belajar $Y$ antara Semua Tingkat Faktor $B$ untuk

Setiap Tingkat Faktor $B$ dengan Mengontrol $X$

\begin{tabular}{|l|r|r|r|l|l|}
\hline \multirow{2}{*}{ Parameter } & \multicolumn{1}{|c|}{$\mathrm{B}$} & \multicolumn{1}{c|}{$\begin{array}{c}\text { Std. } \\
\text { Error }\end{array}$} & \multirow{2}{*}{$t_{\text {hitung }}$} & \multicolumn{2}{|c|}{$t_{\text {tabel }}$} \\
\cline { 4 - 6 } & & & & $\mathrm{a}=0,05$ & $\mathrm{a}=0,01$ \\
\hline Intercept & 64,739 & 3,623 & 17,871 & & \\
$X$ &, 246 &, 047 & 5,269 & & \\
{$[B=1]$} & $-3,290$ & 1,748 & $-1,883$ & & \\
{$[B=2]$} & $0(\mathrm{a})$ &. &. & & \\
{$[B=1]$} & $\mathbf{1 1 , 0 7 6}$ & $\mathbf{1 , 7 0 6}$ & $\mathbf{6 , 4 9 1}$ & $\mathbf{1 , 6 7}$ & $\mathbf{2 , 3 9}$ \\
{$[A=2] *[B=1]$} & $0(\mathrm{a})$ &. &. & & \\
{$[A=2]^{*}[B=2]$} & $0(\mathrm{a})$ &. &. & & \\
\hline
\end{tabular}

Berdasarkan Hasil analisis pengujian hipotesis 6 menunjukkan bahwa nilai statistik uji-t tabel 9. baris $[(B=1)]$ terlihat bahwa pada taraf $a=0.05$, diperoleh nilai $t_{\text {hitung }}=6,491$ lebih besar dari $t_{\text {tabel }}=1,67$ sehingga Ho ditolah, dan disimpulkan bahwa hasil belajar IPA kelompok siswa yang diberi penilaian formatif bentuk tes esai lebih tinggi dibandingkan dengan kelompok siswa yang diberi penilaian formatif bentuk tes pilihan ganda, setelah mengontrol pengetahuan IPA siswa. 


\section{SIMPULAN}

Terdapat perbedaan hasil belajar IPA, kelompok siswa yang diberi penilaian formatif bentuk tes esai dengan kelompok siswa yang diberi penilaian formatif bentuk tes pilihan ganda dengan setelah mengontrol pengetahuan awal IPA siswa.

Hasil belajar IPA kelompok siswa yang diberi penilaian formatif bentuk tes esai lebih tinggi dibandingkan dengan kelompok siswa yang diberi penilaian formatif bentuk tes pilihan ganda dengan mengontrol pengetahuan awal IPA siswa.

\section{CATATAN AKHIR:}

1. E. Mulyasa, Kurikulum Berbasis Kompetensi, Bandung: Remaja Rosdakarya, 2004, h. 5.

2. Munawar Sholeh, Politik Pendidikan Membangun Sumber Daya Bangsa dengan Peningkatan Kualitas Pendidikan, Jakarta: Institute for Public Education, 2005, h. 34.

3. Sumadi Suryabrata, Pengembangan Alat Ukur Psikologi, Yogyakarta: Andi Offset, 2005, h. 249.

4. Djaali, dan Pudji Muljono, Pengukuran dalam Bidang Pendidikan, Jakarta: Grasindo, 2008, h. 9.

5. Colin Rose dan Malcolm J. Nicholl, Cara Belajar Cepat Abad XXI, terjemahan Dedy Ahimsa, Bandung: Yayasan Nuansa Cendekia, 2002, 179.

6. E. R. Hilgard dan G. H. Bowler, Theory of Learning, New Dehli: Prentice Hall of India Privated Ltd., 1977, h. 583.

7. Rodolf Pintner, Educational Psychology, New York: A Division of Harper and Row Publisher, 1970, 104.

8. Robert M. Gagne, Prinsip-Prinsip Belajar untuk Pengajaran, terjemahan Abdillah Hanafi \& Abdul Mana, Surabaya: Usaha Nasional, 1988, h. 18.

9. Nana Sudjana, Penilaian Hasil Proses Belajar Mengajar, Bandung: Remaja Rosdakarya, 1999, h. 86 .

10. Arthur Carin, dan Robert B. Sund, Teaching Science Through Discavery, Columbus: Merrill Publishing Company, 1989, h. 25.

11. Kadaryanto, Biologi I SMP Kelas I, Jakarta: Yudhistira, 2007, h. 2.

12. Norman E. Gronlund, dan Robert L. Linn. Measurement and Evaluation in Teaching, New York: Macmillan Publishing Company, 1990, h. 3.

13. Nana Sudjana, op.cit., h. 21.

14. Benyamin S. Bloom, M. Englehart, E. Furst, W. Hill, dan D. Krathwohl, Taxonomy of Educational Objectives, Handbook 1 Cognitive Domain, New York: Longman Inc, 1987, h. 7.

15. Loren W. Anderson, Kerangka Landasan untuk Pembelajaran, Pengajaran, dan asesmen, terjemahan oleh Agung Prihantoro, Jakarta: Pustaka Pelajar, 2001, h. 40.

16. Ibid., h. 41-45)

17. Leslie J. Briggs, Instructional Design Principles and Applications, Englewood Cliffs, New Jersey: Prentice Hall Inc, 1979, h. 149.

18. Robert M. Gagne, op.cit., h. 3.

19. Martin Tessmer, Planning and Conducting Formative Evaluation, London: Kogan Page Limited, 1995, h. 11.

20. Egon G. Guba, dan Yvonna S. Lincoln. Effective Evaluation. Francisco: Jossey-Bass Publishers, 1988, h. 49.

21. E. Sukardi, dan W. F. Maramis, Penilaian Keberhasilan Belajar, Surabaya: Airlangga University Press, 1986, h. 15. 
22. W. James Popham, Classroom Assessment, What Teachers Need to Know, New Jersey: Allyn \& Bacon, 1994, h. 7.

23. Charles D. Hopkins, dan Richard L. Antes. Classroom Measurement and Evaluation . Illinois: F.E. Peacock Publisher. Inc, 1990, h. 131.

24. Norman E. Gronlund, Constructing Achievement Tests, New Jersey: Prentice Hall Inc, 1982, h. 71.

25. Robert L. Ebel, Essentials of Educational Measurement, New Jersey: Prentice Hall Inc, 1979, h. 95.

26. Albert Oosterhorf, Developing and Using Classroom Assessments, Upper Saddle River, New Jersey, 1996, h. 71.

27. W. James Popham, op.cit., h. 235.

28. Suharsimi Arikunto, Dasar-Dasar Evaluasi Pendididkan, Jakarta: Bumi Aksara, 2008, 164.

29. Anthony J. Nitko, Educational Assessment of Education, New Jersey: Prentice Hall, 1996, h. 176.

30. James S. Cangelosi, Merancang Tes untuk Menilai Prestasi Belajar, terjemahan D. Tedjasudhana, Bandung: Penerbit ITB, 1995, h. 80-81.

31. Anthony J. Nitko, op.cit. h. 141.

32. Charles M. Reigeluth, M. Instructional Design: Theories and Models An Overview of their Curent Status, New Jersey: Lawrence Erelbaum Associations Pub., 1983, h. 88.

33. Oemar Hamalik, Teknik Pengukuran dan Evaluasi Pendidikan, Bandung: Mandar Maju, 2001, h. 40 .

34. W. S. Winkel, Psikologi Pengajaran, Yogyakarta: Media Abadi, 2004, h. 52.

35. Ahmad Tafsir, Metodologi Pengajaran Agama Islam, Bandung: PT Remaja Rosda Karya, 2002, h. 55.

36. I Nyoman S. Degeng, Ilmu Pengajaran Taksonomi Variabel, Jakarta: Depdikbud, 1989, h. 65.

37. Fred N. Kerlinger, Asas-Asas Penelitian Behavioral. Gajamada University Press, 2006.

\section{DAFTAR PUSTAKA:}

Anderson, Loren W., Kerangka Landasan untuk Pembelajaran, Pengajaran, dan asesmen, Terjemahan oleh Agung Prihantoro, Jakarta: Pustaka Pelajar, 2001.

Arikunto, Suharsimi. Dasar-Dasar Evaluasi Pendididkan. Jakarta: Bumi Aksara, 2008.

Bloom, Benyamin S., M. Englehart, E. Furst, W. Hill, dan D. Krathwohl. Taxonomy of Educational Objectives, Handbook 1 Cognitive Domain. New York: Longman Inc, 1987.

Briggs, Leslie J. Instructional Design Principles and Applications. Englewood Cliffs, New Jersey: Prentice Hall Inc, 1979.

Cangelosi, James S. Merancang Tes untuk Menilai Prestasi Belajar. terjemahan D. Tedjasudhana. Bandung: Penerbit ITB, 1995.

Carin, Arthur A., dan Robert B. Sund. Teaching Science Through Discavery. Columbus: Merrill Publishing Company, 1989.

Degeng, I Nyoman S. Ilmu Pengajaran Taksonomi Variabel. Jakarta: Depdikbud, 1989.

Djaali, dan Pudji Muljono. Pengukuran dalam Bidang Pendidikan. Jakarta: Grasindo, 2008.

Ebel, Robert L., Essentials of Educational Measurement, New Jersey: Prentice Hall Inc, 1979.

Gagne, Robert M. Prinsip-Prinsip Belajar untuk Pengajaran. terjemahan Abdillah Hanafi \& Abdul Manan Surabaya: Usaha Nasional, 1988.

Gronlund, Norman E. Constructing Achievement Tests. New Jersey: Prentice Hall Inc, 1982.

Gronlund, Norman E., dan Robert L. Linn. Measurement and Evaluation in Teaching. New York: Macmillan Publishing Company, 1990. 
Guba, Egon G. dan Yvonna S. Lincoln, Effective Evaluation, Francisco: Jossey-Bass Publishers, 1988.

Hamalik, Oemar. Teknik Pengukuran dan Evaluasi Pendidikan. Bandung: Mandar Maju, 2001.

Hilgard , E. R., dan G. H. Bowler. Theory of Learning. New Dehli: Prentice Hallof India Privated Ltd., 1977.

Hopkins, Charles D. dan Richard L. Antes, Classroom Measurement and Evaluation, Illinois: F.E. Peacock Publisher. Inc, 1990.

Kadaryanto. Biologi I SMP Kelas I. Jakarta: Yudhistira, 2007.

Kerlinger, Fred N., Asas-Asas Penelitian Behavioral, Gajamada University Press, 2006.

Mulyasa, E. Kurikulum Berbasis Kompetensi. Bandung: Remaja Rosdakarya, 2004.

Nitko, Anthony J. Educational Assessment of Education. New Jersey: Prentice Hall, 1996.

Oosterhorf, Albert. Developing and Using Classroom Assessments. Upper Saddle River, New Jersey, 1996.

Pintner, Rodolf. Educational Psychology. New York: A Division of Harper and Row Publisher, 1970.

Popham, W. James. Classroom Assessment, What Teachers Need to Know. New Jersey: Allyn \& Bacon, 1994.

Reigeluth, Charles M. Instructional Design: Theories and Models An Overview of their Curent Status. New Jersey: Lawrence Erelbaum Associations Pub., 1983.

Rose, Colin, dan Malcolm J. Nicholl. Cara Belajar Cepat Abad XXI, terjemahan Dedy Ahimsa. Bandung: Yayasan Nuansa Cendekia, 2002.

Sholeh, Munawar. Politik Pendidikan Membangun Sumber Daya Bangsa dengan Peningkatan Kualitas Pendidikan. Jakarta: Institute for Public Education, 2005.

Sudjana, Nana. Penilaian Hasil Proses Belajar Mengajar. Bandung: Remaja Rosdakarya, 1999.

Sukardi, E. dan W. F. Maramis. Penilaian Keberhasilan Belajar. Surabaya: Airlangga University Press, 1986.

Surapranata, Sumarna. Panduan Penilaian Tes Tertulis: Implementasi Kurikulum 2004 . Bandung: Remaja Rosdakarya, 2004.

Suryabrata, Sumadi. Pengembangan Alat Ukur Psikologi. Yogyakarta: Andi Offset, 2005.

Tafsir, Ahmad. Metodologi Pengajaran Agama Islam. Bandung: PT Remaja Rosda Karya, 2002.

Tessmer, Martin. Planning and Conducting Formative Evaluation. London: Kogan Page Limited, 1995.

Undang-Undang Republik Indonesia Nomor 20 Tahun 2003 tentang Sistem Pendidikan Nasional.

Winkel, W. S. psikologi Pengajaran. Yogyakarta: Media Abadi, 2004. 